\title{
Simulation model of single phase PWM inverter by using MATLAB/Simulink
}

\author{
Salam Waley Shneen ${ }^{1}$, Fatin Nabeel Abdullah ${ }^{2}$, Dina Harith Shaker ${ }^{3}$ \\ ${ }^{1}$ Energy and Renewable Energies Technology Center, University of Technology, Baghdad, Iraq \\ ${ }^{2,3}$ Electromechanical department, University of Technology, Baghdad, Iraq
}

\begin{tabular}{l} 
Article Info \\
\hline Article history: \\
Received Mar 7, 2020 \\
Revised Jan 20, 2021 \\
Accepted Feb 1, 2021 \\
\hline
\end{tabular}

Keywords:

Inverter

LC filter

Power electronic

PWM

\begin{abstract}
This work is presenting under the title simulation model of single phase PWM inverter by using MATLAB/Simulink. There are many researchers' works in this field with the different ways because it is important field and it has many applications. The converter DC power to AC power for any system that mean it need the power electronic device (inverter). The inverter is using when the source DC power and the load AC power. In this work, the simulation system includes the source $300 \mathrm{~V}$ DC power, inverter, LC filter and load (R). The simulation result shows the waveform of all part in this system like input and output current and voltage.
\end{abstract}

This is an open access article under the CC BY-SA license.

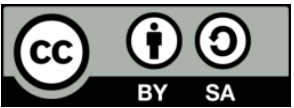

\section{Corresponding Author:}

Salam Waley Shneen

Energy and Renewable Energies Technology Center, University of Technology

52 Industry street, Baghdad, Iraq

Email: salam_waley73@yahoo.com

\section{INTRODUCTION}

Power electronic, there are four kind for power electronic device AC-AC, DC-DC, AC-DC and DCDC [1]-[5]. The AC-AC is called converter also the DC-DC is called converter, the AC-DC is called rectifier and DC-AC is called inverter that device is using in this work [6]-[9]. Inverter, it uses to convert DC power to AC power for any system [10]-[12]. The inverter is one of the parts of the renewable energy systems (wind energy or the photovoltaic system) and has many industrial applications such as UPS [13]-[15]. Adopting the pulse width rate to control the output voltage of the inverter through the stimulation pulses of the inverter switch gates [16]-[21]. The inverter voltage changes with the change in load, so I found the need for a control process to stabilize the voltage by controlling the inverter output (correcting and setting) according to the load value [22]-[26]. The current study includes a reflector with a pulse width rate, and the study is using a computer program that helps simulate the system designed for the current study. By setting different criteria to study different cases to determine the response of the system. Moreover, to address instabilities within the design boundaries of the system used and to reach the best model can give a high response and a short time.

\section{THE SIMULATION MODEL}

The Simulation model of single phase PWM inverter by using MATLAB as shown in Figure 1, that include voltage source $\left(\mathrm{V}_{\mathrm{DC}}=300 \mathrm{~V}\right)$, LC filter $(\mathrm{L}=2 \mathrm{mH}$ and $\mathrm{C}=11$ microF $)$, Load resitance $(\mathrm{R}=1 \mathrm{ohm})$, PWM as shown in Figure 2 and inverter as shown in Figure 3. The simulation model of PWM that had input $\&$ output, input (sine wave, sawtooth and comparative) and output had pulses. The simulation model of single 
phase inverter that had input \& output, input had ( $\mathrm{V}_{\mathrm{DC}} \&$ pulses) and the output had $\mathrm{V}_{\mathrm{AC}}$. That the connected to input filter after filter connect to the load.

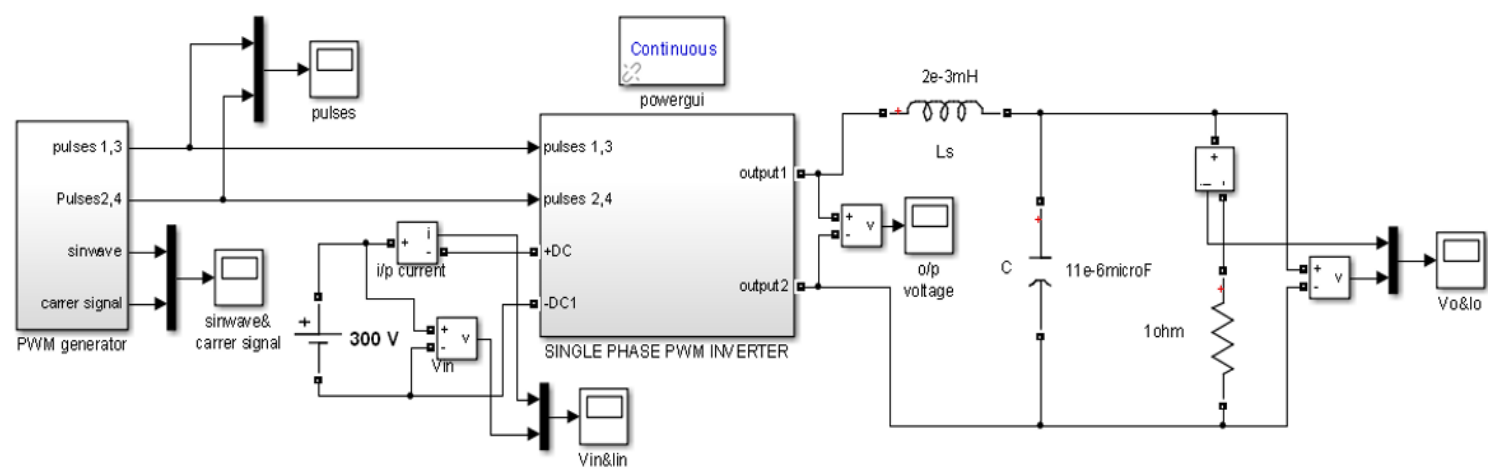

Figure 1. Simulink model of single phase PWM inverter

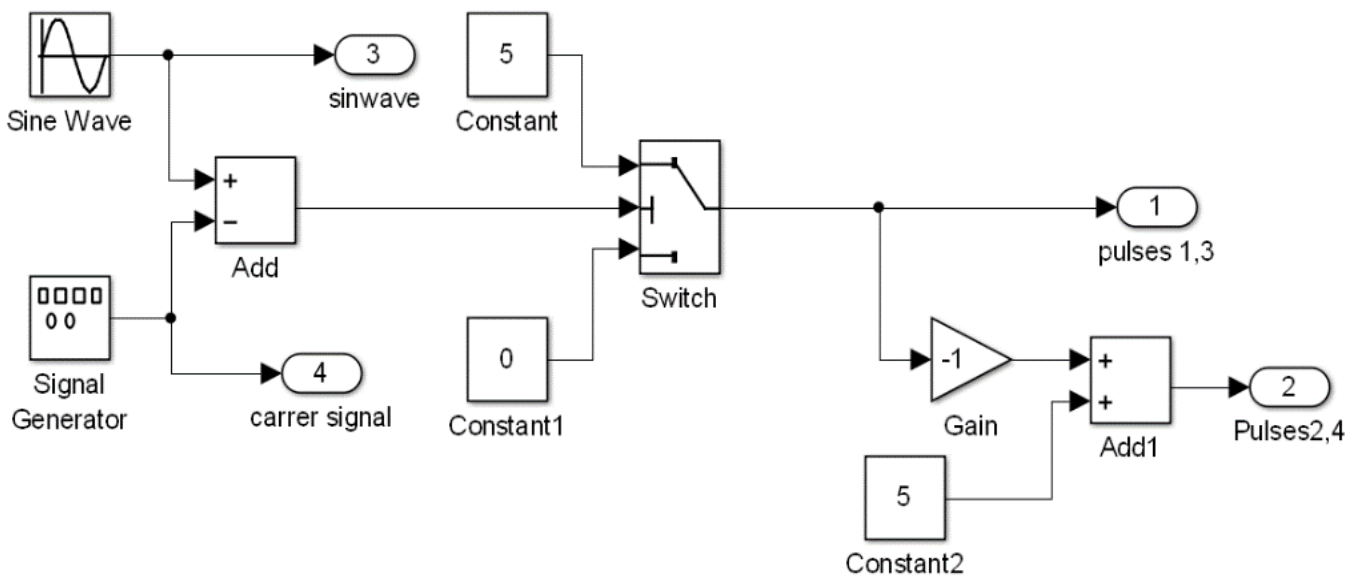

Figure 2. Simulink model of PWM

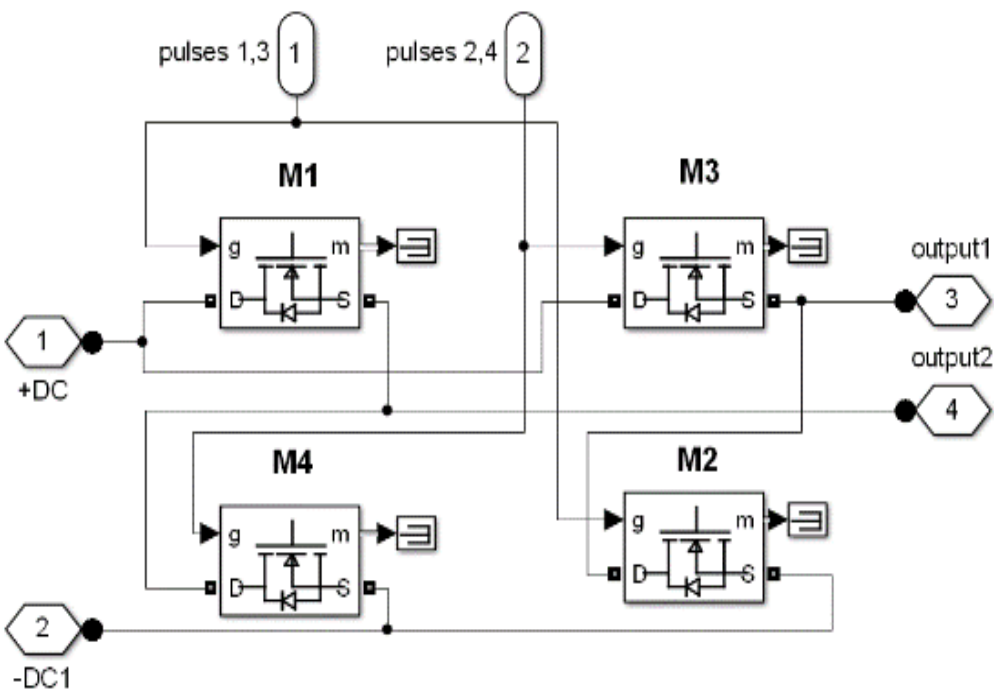

Figure 3. Simulink model of single-phase inverter 


\section{SIMULINK RESULTS}

The Simulink results have many parts include simulink voltage and current input system as show in Figure 4, Simulink input filter as show in Figure 5 and simulink voltage and current output system as show in Figure 6.

\subsection{Simulink voltage and current input system}

In this part, the simulink voltage and current input system as show in Figure 4. By using $300 \mathrm{~V}_{\mathrm{DC}}$ input to $100 \mathrm{~V}_{\mathrm{AC}}$ output. Options have been developed to conduct the test for the proposed system that adopts the circuit feeding a 300 volt continuous voltage source to obtain experimental results as in the figure above, the result in Figure 4. Show the input voltageVin $=\mathrm{VDC}=300$ Volts and input current Iin (A).

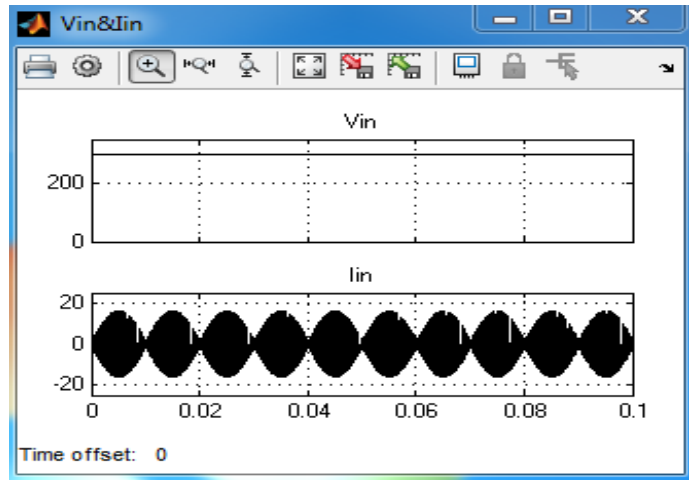

Figure 4. Simulink result of voltage and current input system

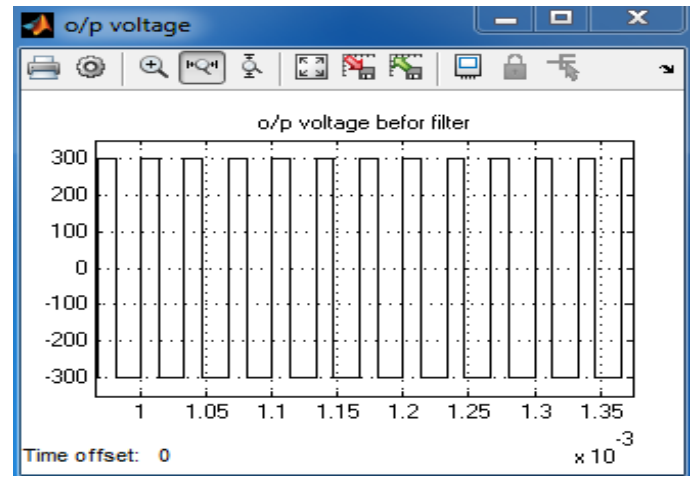

Figure 5. Simulink result for voltage of input filter

\subsection{Simulink voltage of input filter}

In this part, the Simulink input filter as show in Figure 5. The second stage is the candidate whose income is the output of the first stage, which can be obtained through the results shown in Figure 5. That show the output voltage before filter.

\subsection{Simulink voltage and current output system}

In this part, the simulink result voltage and current output system as show in Figure 6. By using 300 $\mathrm{V}_{\mathrm{DC}}$ input to $100 \mathrm{~V}_{\mathrm{AC}}$ output (DC to $\mathrm{AC} \mathrm{PWM}$ ), LC filter ( $\mathrm{L}=2 \mathrm{mH} \& \mathrm{C}=11 \mathrm{microF}$ ) and load (R) in ohm.

\subsection{Simulink pulses and carrer signal}

In this part, in simulation of DC to AC PWM inverter. In this simulation model consisting of four mosfet that had amplitude gate pulses $5 \mathrm{~V}$ selected Mosfet with $1 \mathrm{kHz}$ frequency switching. The simulink pulses in Figure 7, sine wave in Figure 8 and carrer (sawtooth) signal as show in Figure 9.

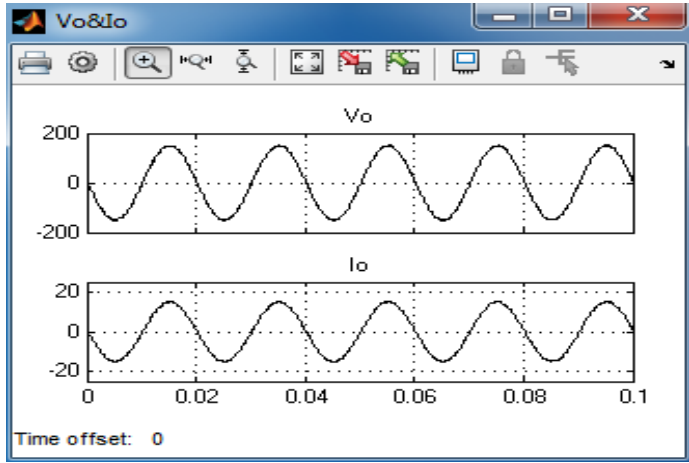

Figure 6. Simulink result of voltage and current output system

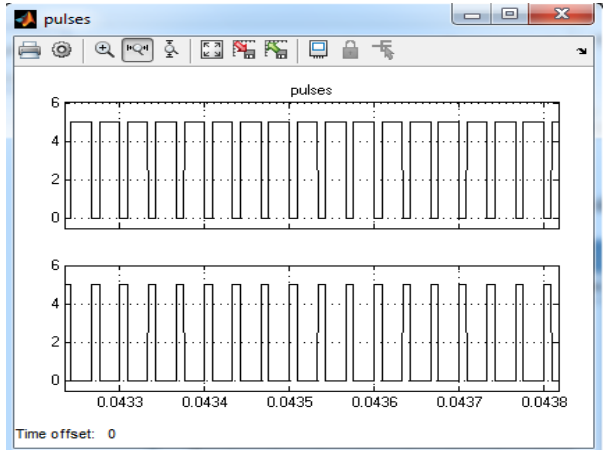

Figure 7. Simulink pulses 


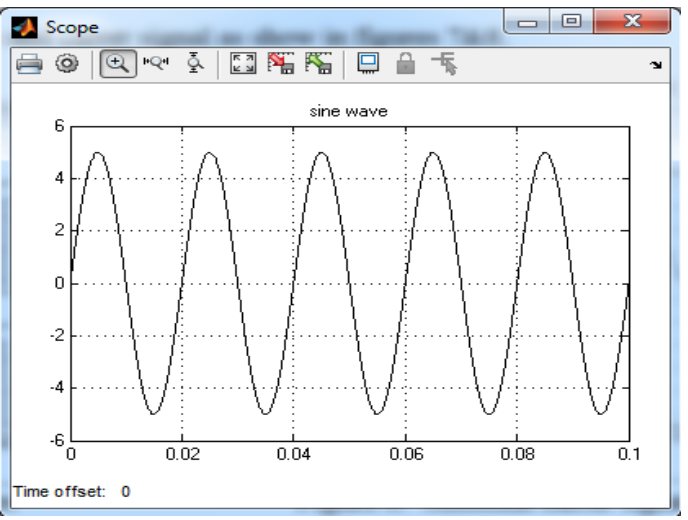

Figure 8. Simulink sine wave

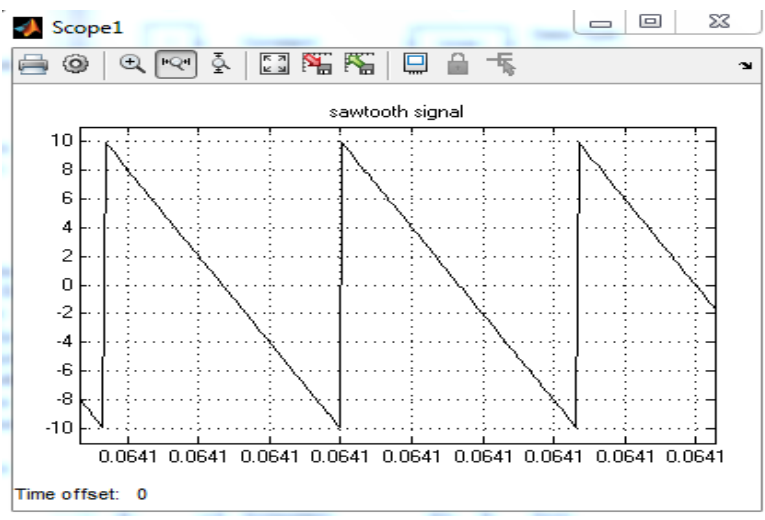

Figure 9. Simulink carrer signal

\section{CONCLUSION}

The characteristic of this system includes first the parameters of DC-AC inverter like switching type diode, transistor or thirestor. Second, the characteristic of PWM like amplitude value and frequency. Finally, the filter and load characteristic and types like LC filter and Rload. In simulation of DC to AC PWM inverter, selected Mosfet with $1 \mathrm{kHz}$ frequency switching for 300VDC input to more than 100VAC output. Simulation of this proposed model for voltage regulation was conducted with the aim of validating system, simulation results show that the proposed system can be used effectively in many Applications that fit the specifications of the proposed system.

\section{REFERENCES}

[1] Palanidoss, Sriramalakshmi, and V. T. Sreedevi., "Experimental verification of three phase quasi switched boost inverter with an improved PWM control," International Journal of Power Electronics and Drive Systems (IJPEDS), vol. 10, no. 3, pp. 1500-1509, 2019.

[2] Rasin, Zulhani, et al., "Design and Development of Grid-connected Quasi-Z-Source PV Inverter," International Journal of Power Electronics and Drive Systems (IJPEDS), vol. 9, no. 4, pp. 1989-2005, 2018.

[3] Shneen, Salam Waley, "Advanced Optimal for Three Phase Rectifier in Power-Electronic Systems," Indonesian Journal of Electrical Engineering and Computer Science (IJEECS), vol. 11, no. 3, pp. 821-830, 2018.

[4] Saleh, Kamel, and Naeil Hantouli, "A photovoltaic integrated unified power quality conditioner with a 27-level inverter," TELKOMNIKA Telecommunication, Computing, Electronics and Control, vol 17, no. 6, pp. 3232-3248, 2019.

[5] Radaydeh, Nuha M., and M. R. D. Al-Mothafar, "Small-signal modeling of current-mode controlled modular DCDC converters using the state-space algebraic approach," International Journal of Electrical \& Computer Engineering, vol. 10, no. 1, pp. 139-150, 2020.

[6] Salam Waley, Chengxiong Mao, "Artificial Optimal Fuzzy Control Strategy for Elevator Drive System by Using Permanent Magnet Synchronous Motor," TELKOMNIKA Telecommunication, Computing, Electronics and Control, vol. 14, no. 3, pp. 470-480, 2015.

[7] Selmi, Tarek, and Maher Rezgui, "A Novel DC-AC Inverter Topology to Eliminate Leakage Current," International Journal of Power Electronics and Drive Systems (IJPEDS), vol. 9, no. 4, pp. 1733-1744, 2018.

[8] Reddy, K. Rajasekhara, V. Nagabhaskar Reddy, and M. Vijaya Kumar, "Control of Single Stage Grid Tied Photovoltaic Inverter Using Incremental Conductance Method," International Journal of Power Electronics and Drive Systems (IJPEDS), vol. 9, no. 4, pp. 1702-1708, 2018.

[9] Shneen, Salam Waley, Mohammed Qasim Sulttan, and Manal Hadi Jaber, "Variable speed control for 2Ph-HSM in RGS: a comparative simulation study," International Journal of Electrical and Computer Engineering (IJECE), vol. 10, no. 3, pp. 2285-2295, 2020.

[10] Sayed, Hussain, et al., "Symmetrical high voltage gain half-bridge inverter based double-Y-source networks with reduced voltage stress," International Journal of Power Electronics and Drive Systems (IJPEDS), vol. 11, no. 1, pp. 515-522, 2020.

[11] Lagssiyer, Brahim, Aziz Abdelhak, and Mohamed El Hafyani, "Performance assessment, in terms of ripples and power, of conventional and interleaved converter DC-DC with coupled and independent inductors dedicated to photovoltaic installations," Indonesian Journal of Electrical Engineering and Computer Science (IJEECS), vol. 14, no. 2, pp. 978-989, 2019.

[12] Shneen, Salam Waley, et al., "Design and implementation of variable and constant load for induction motor," International Journal of Power Electronics and Drive Systems (IJPEDS), vol. 11, no. 2, pp. 762-773, 2020.

[13] Zulkifli, M. Z., et al. "Simple control scheme buck-boost DC-DC converter for stand alone PV application system," International Journal of Power Electronics and Drive Systems (IJPEDS), vol. 10, no. 2, pp. 1090-1101, 2019. 
[14] Shneen, Salam Waley, et al., "Advanced optimal by PSO-PI for DC motor," Indonesian Journal of Electrical Engineering and Computer Science (IJEECS), vol. 16, no. 1, pp. 165-175,2019 .

[15] Kadum, Arkan A., "PWM control techniques for three phase three level inverter drives," TELKOMNIKA Telecommunication, Computing, Electronics and Control, vol. 18, no. 1, pp. 519-529, 2020.

[16] Khleaf, Hussain K., Ali Kareem Nahar, and Ansam Subhi Jabbar, "Intelligent control of DC-DC converter based on PID-neural network," International Journal of Power Electronics and Drive Systems (IJPEDS), vol. 10, no. 4, pp. 2254-2262, 2019.

[17] Alhamrouni, Ibrahim, et al., "Design and development of SEPIC DC-DC boost converter for photovoltaic application," International Journal of Power Electronics and Drive Systems (IJPEDS), vol. 10, no. 1, pp. 406-413 2019.

[18] Attiya, Adnan Jabbar, et al., "Variable Speed Control Using Fuzzy-PID Controller for Two-phase Hybrid Stepping Motor in Robotic Grinding," Indonesian Journal of Electrical Engineering and Computer Science (IJEECS), vol. 3, no. 1, pp. 102-118, 2016.

[19] Trujillo, O. A., Toro-García, N., \& Hoyos, F. E., "PID controller using rapid control prototyping techniques," International Journal of Electrical \& Computer Engineering (IJECE), vol. 9, no. 3, pp. 1645-1655, 2019.

[20] Shneen, Salam Waley, Chengxiong Mao, and Dan Wang, "Advanced optimal PSO, Fuzzy and PI controller with PMSM and WTGS at $5 \mathrm{~Hz}$ side of generation and 50Hz Side of Grid," International Journal of Power Electronics and Drive Systems (IJPEDS), vol. 7, no. 1, pp. 173-192, 2016.

[21] Jidin, Auzani, and Tole Sutikno, "MATLAB/Simulink based analysis of voltage source inverter with space vector modulation," TELKOMNIKA Telecommunication, Computing, Electronics and Control, vol. 7, no. 1, pp. 23-30, 2009.

[22] Nordin, Norjulia Mohamad, et al., "Constant frequency torque controller for DTC with multilevel inverter of induction machines," International Journal of Power Electronics and Drive Systems (IJPEDS), vol. 7, no. 1, pp. 28-44, 2016.

[23] Uthman, A., \& Sudin, S., "Antenna Azimuth Position Control System using PID Controller \& State-Feedback Controller Approach," International Journal of Electrical \& Computer Engineering (IJECE), vol. 8, no. 3, pp. 1539-1550, 2018.

[24] Bharatiraja, C., et al., "A simple switching on-time calculation revision in multilevel inverter-space vector modulation to achieving extended voltage boundary operation," International Journal of Power Electronics and Drive Systems (IJPEDS), vol. 10, no. 2, pp. 653-661, 2019.

[25] Shneen, Salam Waley, "Advanced Optimal for PV system coupled with PMSM," Indonesian Journal of Electrical Engineering and Computer Science (IJEECS), vol. 1, no. 3, pp. 556-565, 2016.

[26] Ali, Syed Munvar, V. Vijaya Kumar Reddy, and M. Surya Kalavathi, "Coupled random PWM technique for dual inverter fed induction motor drive," International Journal of Power Electronics and Drive Systems (IJPEDS), vol. 10, no. 1, pp. 58-65, 2019. 